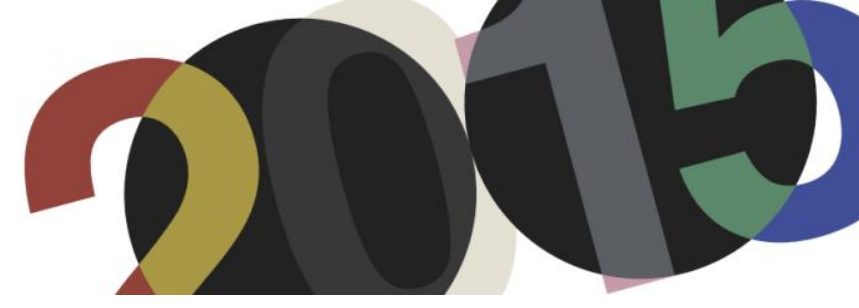

DOI: http://dx.doi.org/10.4995/LC2015.2015.584

\title{
Le Corbusier's Musée à croissance illimitée: A Limitless Diagram for Museology
}

\author{
I. Chin \\ Harvard Graduate School of Design
}

\begin{abstract}
Let us imagine a true museum, one that contained everything, one that could present a complete picture after the passage of time, after the destruction by time...” This paper considers La Musée à croissance illimitée, an unrealized proposal from 1939 by Le Corbusier in which a series of galleries elevated on pilotis and organized about a square courtyard would extend - infinitely. The paper unfolds as an analysis of the museum and its relationship to history and time, structured by the form of Le Corbusier's proposal. Four themes establish the parameters of the investigation - spatial organization, notions of monumentality, relationship to site, and ideas of growth - and Le Corbusier's resistant approach is considered as a method of criticality. Order-less, face-less, place-less, end-less. To categorize the Museum of Unlimited Growth as such is not to suppose conditions without, conditions of lack, or absence; but rather is a means to consider the proposal as an absolutea degree zero that subsumes and thus allows for conditions of possibility. The themes set up a dialectical reading of the project, as its negations are bound to the assertive, positivity of the idea of a limitless spiral. Perpetually unfolding and folding in on itself, the Musée resists the forces of time. It is the ur-museum, a concept that negates the historiography of museums before and proposes an impossible model for museums to come.
\end{abstract}

Keywords: museum; limitless; growth; spiral.

Palabras clave: museo; límites; crecimiento; espiral.

\section{Introduction}

"The museum is bad because it does not tell the whole story.

It misleads, it dissimulates, it deludes. It is a liar. "1

Le Corbusier was a harsh critic of the museum as institution. Published as a letter to the editor of Cahiers d'art, in 1931, his Musée a croissance illimitée, Museum of Unlimited Growth, was a radical proposal, for a seemingly contradictory architecture that is at once retrospective and projective. It is self-referential, and in its primitive form and oppositional approach, becomes myth and metaphor.

Each section in this paper opens with a direct quotation from the original proposal to consider the order-less, face-less, place-less, end-less, qualities of the project. These themes are presented as such to be polemical, as an interpretation of the Museum of Unlimited Growth as a counter-narrative to the typical museum as monument. Through these negations, the Musée stands as a degree-zero for architecture, a time-less symbol. The analysis attempts to interpret its complexities and paradoxes, in order to reveal a clearer picture of the museum as Le Corbusier envisioned. Within the proposal's text and drawings lies a discrete and continuous structure, a formal philosophy, a framework for architecture's relationship to history and time.

\footnotetext{
${ }^{1}$ Le Corbusier quoted in Calum Storrie, The Delirious Museum: A Journey from the Louvre to Las Vegas, London: I.B. Tauris, 2006.
} 


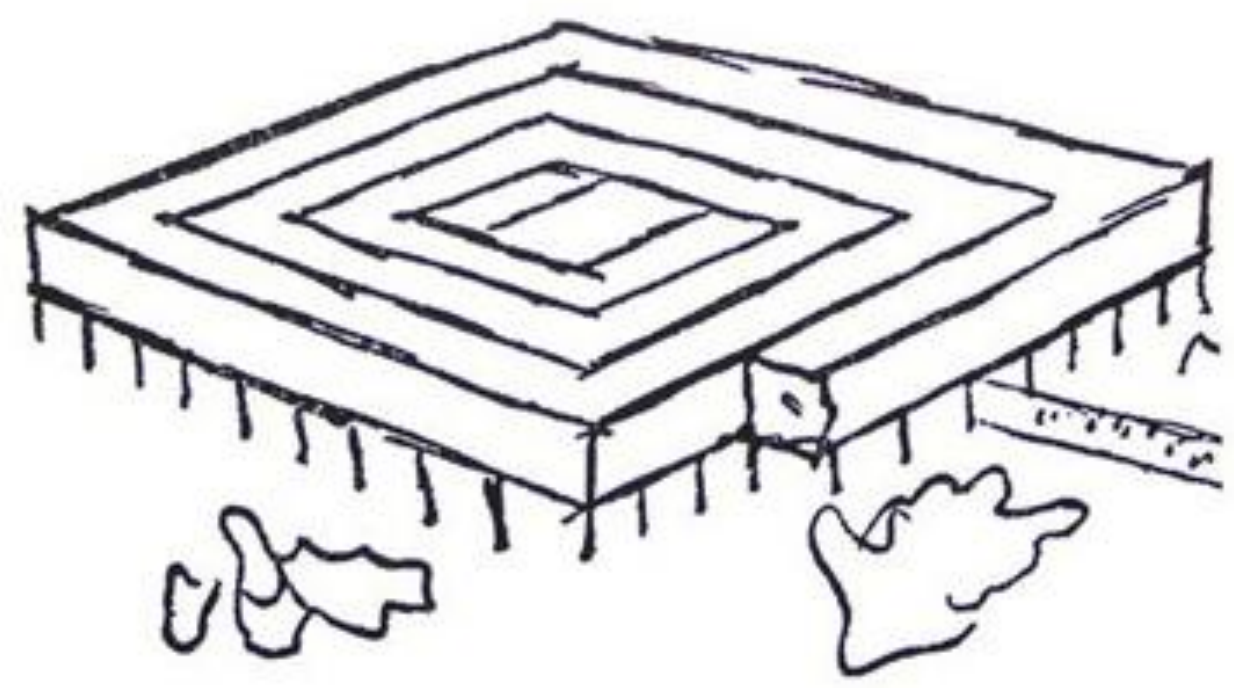

1. Musée à croissance illimitée, Euvre Complète. (C) FLC/ADAGP

\section{Order-less}

C'est un moyen d'arriver à faire construire à Paris un musée dans des conditions qui ne soient pas arbitraires, mais au contraire suivant des lois naturelles de croissance qui sont dans l'ordre selon lequel se manifeste la vie organique: un élément étant susceptible de s'ajouter dans l'harmonie, l'idée d'ensemble ayant précédé l'idée de la partie. $^{2}$

Le Corbusier would have been challenging the model of Jean Nicholas Louis Durand (1760-1834). In his Project for a Museum in 1803, Durand set the standard for the spatial representation of art history. Interpreted as abstract descendants of temples, early prototypes of museums were designed with a parti to describe a ritual of culturalization. Prominent elements of Beaux-Arts compositions ${ }^{3}$ would have included cour d'honneur (forecourt flanked by extended wings), corps de logis (main building), garden courts, and grand escalier. Monumental stairways and vestibules established thresholds of transition from external, profane space; while codified plans established a choreography through interior, sacred space. History unfolded along symmetrical axes, in sequential period rooms, with each branch of the major arts relegated to its own distinct quarter.

Le Corbusier's Museum of Unlimited Growth eschewed any of these elements and ideas of hierarchy. Its general form and massing can be seen through photographs of the maquette; and the master plan and logic of extension through drawings from the original article. The Musée opened from within a 14x14 meter square courtyard, and

\footnotetext{
${ }^{2}$ This is an approach to build a museum in Paris, not under arbitrary conditions, but one that follows laws of natural growth, in the order in which organic life manifests: an element contributing to harmony, this overarching concept precedes an idea of its parts. Le Corbusier and Pierre Jeanneret, "Pour la création a Paris d'un musée des artistes vivants," Cahiers d'art, année 6, no.1 (1931): 5-9.

${ }^{3}$ Helen Searing. New American Art Museums (New York, NY: Whitney Museum of American Art, 1982): 44.
} 
spiraled outward following a 7x7 meter grid. These galleries would extend incrementally, the museum growing along with its collection - an organic and harmonious architecture for the synthesis of arts.
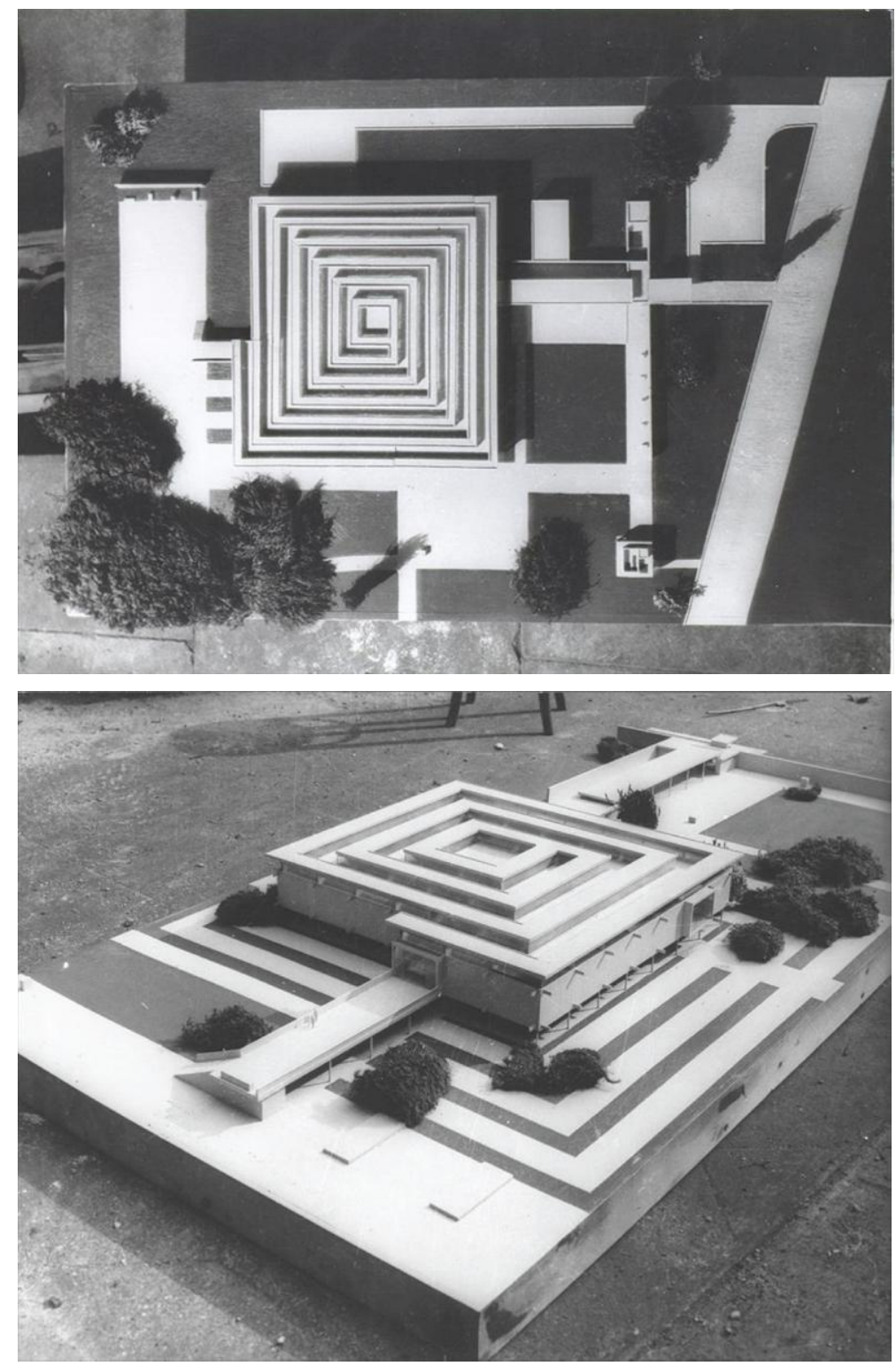

\section{2 - 3. Musée à croissance illimitée, maquette. @ FLC/ADAGP}

As an artist in his own right, from paintings, sculpture, tapestries, to murals, Le Corbusier produced artwork at massive scales. Having had exhibitions of his own and having had clients who were art collectors, he had experience with the complexities of display and was attune to scale and setting of art work. After participating in an exhibition at the National Museum of Modern Art in Paris, he would denounce the space to be inhuman "Legitimate works of art are tampered with in such a place losing their true relationship with man, for whom alone, when all is said and done, they are intended. ${ }^{, 4}$ Le Corbusier was therefore sensitive in addressing the relationship of the body to artwork. Although there are common standards for museums in terms of installation heights and spacing, in the total design of his museums Le Corbusier would describe the galleries to be multi-

\footnotetext{
${ }^{4}$ Le Corbusier. Le Modular II (Paris, 1948): 261.
} 
level and nuanced spaces with differentiated views. With interior details following the logic of the modular, Le Corbusier's museums were machines for viewing art.

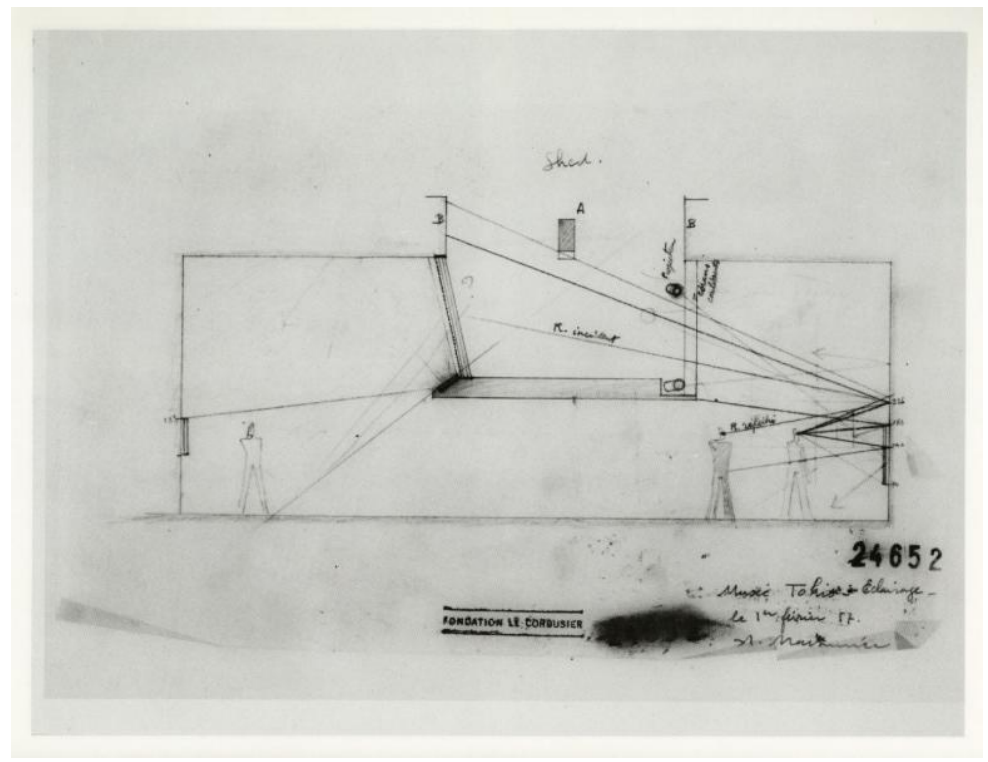

4. National Museum of Western Art, section. (C) FLC/ADAGP

There are three projects following Le Corbusier's concept for the Musée: the Sanskar Kendra Museum at Ahmedabad (1952-54), the Chandigarh Museum and Art Gallery (1947-1952), and the National Museum of Western Art in Tokyo (1957-59). These commissions came after several other attempted proposals, and were only built later in Le Corbusier's life. As with all utopian schemes, the resolution of the spiral plan varies in its realized iterations. Multiple entry/exit ways, auditoria, and landscape elements seen in plan violate the purity of the original drawing. However, despite the clarity in form of the Museum of Unlimited Growth, the project was always conceived as being part of a larger complex. Prescient of the evolution and demands of artistic practice, Le Corbusier understood the need for flexible performance spaces and planned areas for large scale sculptures. He was also aware that a cultural institution would need spaces for research and education. And before whitecube galleries or black-box theatres - there was Le Corbusier's box of miracles ${ }^{5}$ to accommodate various media and experiences. The square spiral museum would house permanent collections and there were to be pavilions for temporary exhibitions to supplement the greater narrative.

In terms of interior details, natural light would filter in through clerestories throughout the day and seasons, working in conjunction with multiple systems of artificial lighting. Whereas the sketches of the original proposal and the Indian museums have an open air courtyard, the National Museum of Western Art has unique skylights to create dramatic, yet functional gallery spaces. A model of the Museum of Unlimited Growth was included in Modular II as part of a series of projects (number eleven of twenty-three) ${ }^{6}$ illustrating the scope of Le Corbusier's mathematical ideas and how they can be carried across all scales, from the domestic object to the

\footnotetext{
5 "La boîte à miracles enclosing all that your heart desires. Scenes and actors materialize the moment the miracle box appears; the miracle box is a cube; with it comes everything that is needed to perform miracles, levitation, manipulation, distraction, etc. The interior of the cube is empty, but your inventive spirit will fill it with everything you dream of in the manner of performances of the old Commedia dell'Arte." Le Corbusier quoted in Massilia, La Boîte à miracles - Le Corbusier et le théâtre : annuaire 2012 de la Fondation Le Corbusier (Paris: Fondation Le Corbusier; Marseille: Imbernon, 2012).

${ }^{6}$ Le Corbusier. Le Modular II, 176.
} 
very conception of a great city. Proportion and harmony create order to the experience of the museum, allowing art objects to speak for themselves. Architecture, here, supports a fluid unfolding narrative rather than an exacting art-historical structure. The curatorial challenge then, is to program the spaces of the museum according to the movement along the architectural promenade. ${ }^{7}$ The museum of unlimited growth presented a spatial reconfiguration for aesthetic experience. Robert Slutzky, painter and architectural theorist, has suggested "the ramp allows the observer to enter a building as the eye enters a painting, at the center of its spatial field, as opposed to the hierarchical stacking of a classical façade. ${ }^{\prime 8}$ The challenge that modern art posed to the viewer was a redefinition of perspective and relationship between the body and the art object. surface, and space. The human eye, in its investigations, is always on the move and the beholder himself is always turning right and left, and shifting about. He is interested in everything and is attracted towards the centre of gravity of the whole site. ${ }^{9}$

Unlike the circular dome which Durand's museum is fixed upon, the square figure at the center of Le Corbusier's museum is a dynamic field from which the museum opens. Painting, sculpture, and architecture meet, animated by the movement embedded within the architectural form of the Musée. With the absolute diagram of the spiral, Le Corbusier subverted preconceived notions of museological order and provided a space for the synthesis of arts. The spiral diagram which organized Le Corbusier's ideal museum, was therefore a framework for intellectual organization in the mind, rather than on the perceptual level of the eye.

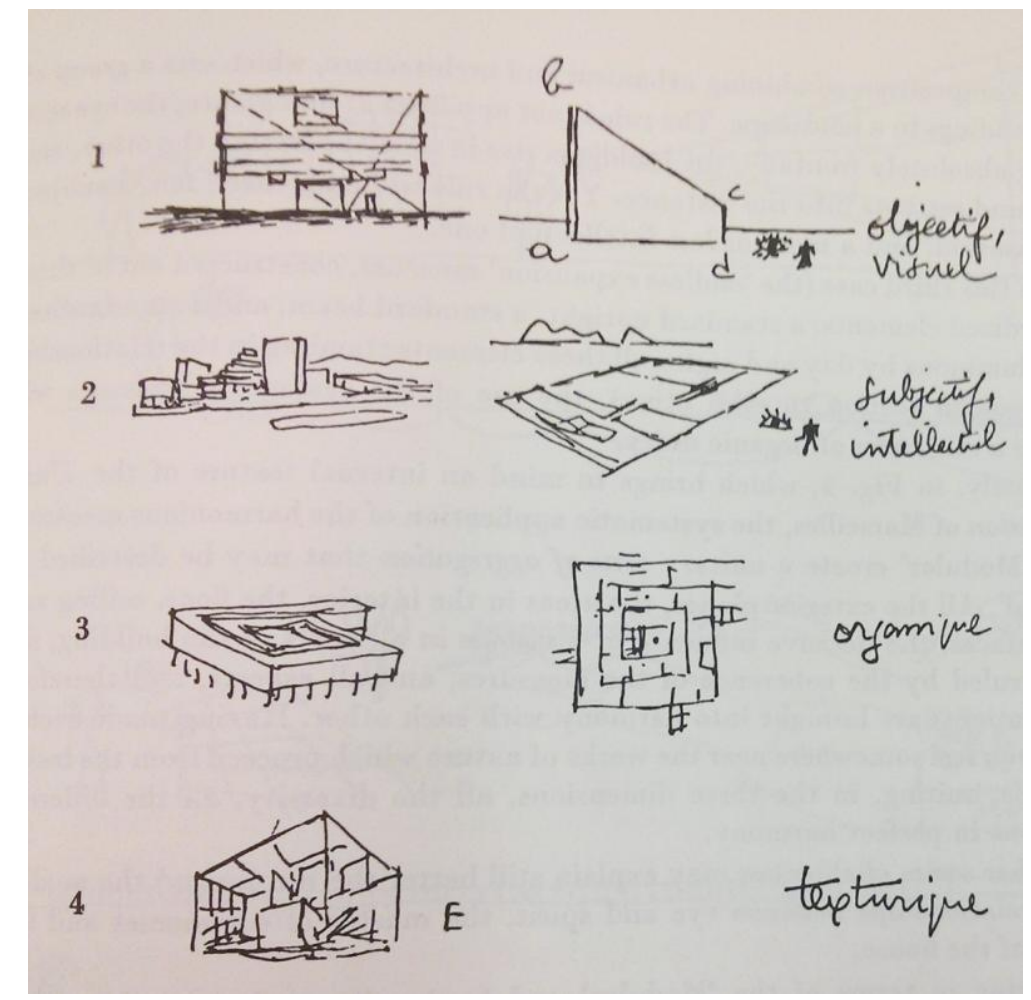

5. “organize," Modular II.

\footnotetext{
${ }^{7}$ Discussed extensively in Flora Samuel, Le Corbusier and the Architectural Promenade (Basel: Birkhäuser, 2010).

${ }^{8}$ Stanely Allen, "Le Corbusier and Modernist Movement," Any 1, no.5 (March 1994): 42.

${ }^{9}$ Le Corbusier. Vers une architecture (Paris: G. Crès et Cie, 1924): 191.
} 


\section{Face-less}

Le musée n'a pas de façade, le visiteur ne verra jamais de façade; il ne verra que l'intérieur du musée. ${ }^{10}$

While the structuring of this paper around oppositional terms is the product of my own extrapolation and analysis, face-less-ness is one idea that is directly legible in Le Corbusier's writing. He himself described his spiral museums as FRONTLESS ${ }^{11}$ in the retrospective monograph, Creation is a Patient Search. And in his original proposal, this idea is especially evident, emphasized through the repetitive use of negational terms. One would walk through the gate into a covered pathway, straight towards the center of the spiral without confronting any sort of monumental facade. Colin Rowe once said - "Face was never a preoccupation of modern architecture. ${ }^{, 12}$ However, this implies a inconsequential neglect, for the sake of emphasizing other, over-arching ideas. I will argue that in the case of the Museum of Unlimited Growth, the treatment of the building's elevation is loaded with intentionality and reflects a deliberate mode of resistance.

In Renaissance, humanist analogy, architecture is directly related to the body, and a building's façade is that body's face and means of expression. A perceptual understanding of a building is therefore understood visually via its elevation, as opposed to a conceptual plan diagram, perceived intellectually through spatial experience. Georg Simmel offers a similar reading within nineteenth century critical theory, of a building's façade as revealing of building's soul and personality, and by extension, the architect's soul and personality. The face of a building functions as an architectural representation of a contemporary historical moment. If a facial expression is a projection of an internal condition, in its allegorical role, a building's façade bound to its contents represents a moment of "cultural crystallization." ${ }^{\text {"13 }}$ Returning to Rowe's comment, however, there is a general sense in the twentieth century of a dissociation with these ideas and the role of "face" - where the monotony of glass towers is an expression of lightness and dematerialization, but signifies a social derealization and disembodiment. ${ }^{14}$

In the particular case of museums, architectural expression must negotiate with the artistic expression for which it is meant to support. Georges Bataille once noted, "one must take account of the fact that the rooms and objects of art are only a container the content of which is formed by the visitors." forces, museums' outward projection of civic iconicity, and inward tension between art object and functional space. Le Corbusier's Musée with its spiral order and face-less elevation subsumes and confronts this issue, challenging precedents which came before.

\footnotetext{
${ }^{10}$ The museum has no façade; the visitor will never see a façade; he will only see the interior of the museum.

${ }^{11}$ Le Corbusier. L'atelier de la recherche patiente (New York: Praeger, 1960): 97.

${ }^{12}$ Colin Rowe quoted in Anthony Vidler, "Losing Face: Notes on the Modern Museum," Assemblage no. 9 (June 1989): 41.

${ }^{13}$ A. Vidler, Warped Space: Art, Architecture, and Anxiety in Modern Culture (Cambridge, MA: MIT Press, 2000).

${ }^{14}$ Vidler, "Losing Face: Notes on the Modern Museum," 53.

${ }^{15}$ Georges Bataille quoted in Vidler, The Architectural Uncanny: Essays in the Modern Unhomely (Cambridge, MA: MIT Press, 1992): 98.
} 


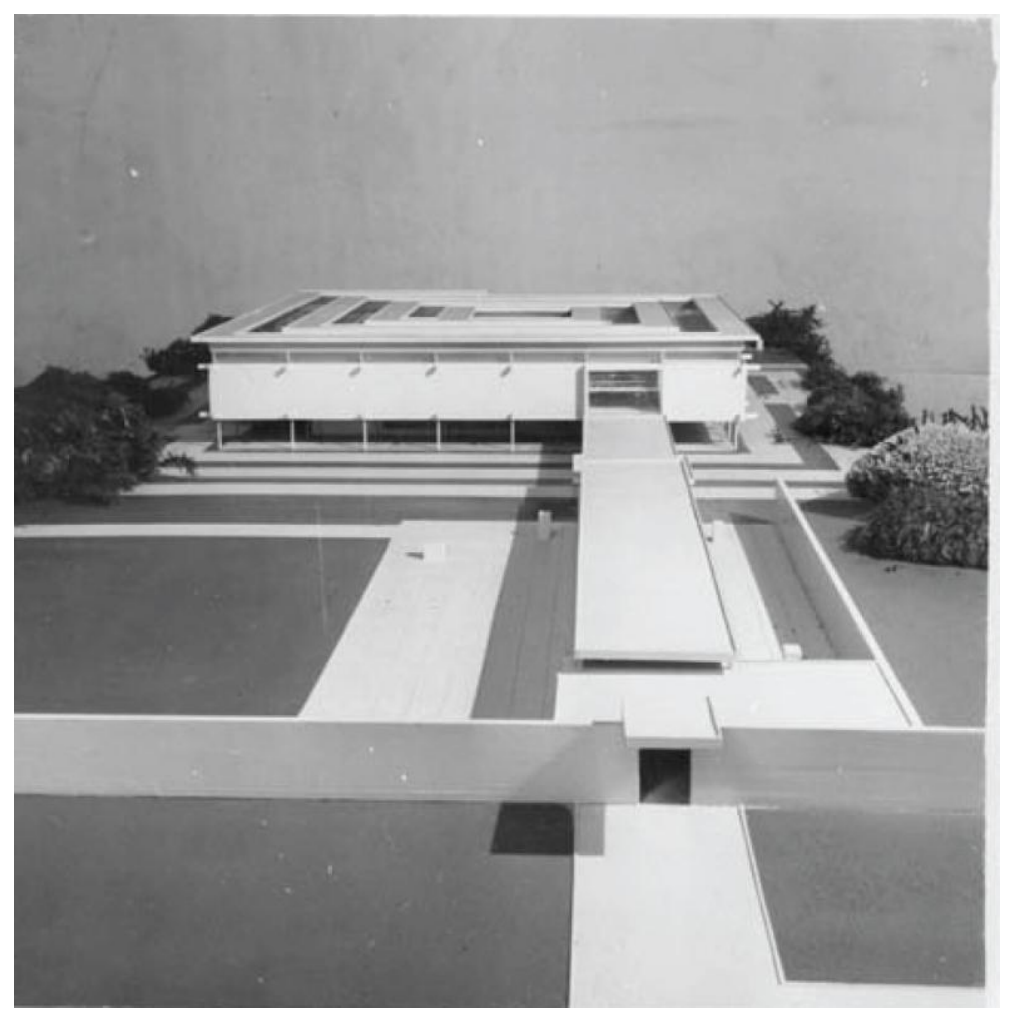

6. Musée à croissance illimitée, maquette. (C) FLC/ADAGP

Museums came to be expressions of nationalism after Napoleonic wars and cultural pillaging across Europe. This is best exemplified by Karl Friedrich Schinkel's Altes Museum. With its giant order of eighteen Ionic columns, the Altes Museum has a very deliberate face and connection to the city of Berlin. In the context of revolutionary Prussia, the other three sides of the building were modest brick surfaces with emphasis and investment on the monumental entry way, marked with: FRIDERICUS GUILELMUS III STUDIO ANTIQUITATIS OMNIGENIAE ET ARTIUM LIBERALIUM MUSEUM CONSTITUIT MDCCCXXVIII" ("Friedrich Wilhelm III dedicated this museum to the study of all antiquity and liberal arts in 1828") The inscription is significant in its projection of a national identity and pronouncement of the concept of bildung, or cultural and self-cultivation. Nineteenth century institutions would generally follow this classical model, creating sacred spaces, alluding to temples of antiquity, expressing transcendental aspirations and democratic, secular intentions. Twentieth century institutions, liberated from the role of symbols for nation-states or monuments for democracy and civic pride, then became icons of technological progress. In the post-modern era, architecture becomes image and spectacle ${ }^{16}$.

Tension emerges where architecture's function as frame, in relation to its autonomy as a self-serving art object, has become ambiguous. Architectural authority conflicts with artistic and curatorial intention. Hal Foster will call this the Art-Architecture Complex ${ }^{17}$ where spaces, under pressures and demands of consumer capitalism, have become a field in which structure, surface and symbol are collapsed and difficult to distinguish. Architectural practice has always found ways of expression through technology and materials but in modernity, this expression, as it has in artistic practice, has become pop image.

\footnotetext{
${ }^{16}$ Vidler, Architecture between Spectacle and Use (Williamstown, MA: Sterling and Francine Clark Art Institute, 2008).

${ }^{17}$ Hal Foster, The Art-Architecture Complex (London: Verso, 2011).
} 
Le Corbusier's free facade is not pictoral or superficial - that is, of the surface - but rather, volumetric and total. It is liberated from structural function but then resists any form of social function or cultural representation. Le Corbusier recommended that "a mason and a labourer be permanently employed in building this museum in an uninterrupted and perennial operation" ${ }^{\prime 18}$ - as the museum would be constantly under construction, a continuous wall unfolding and folding in on itself. As represented in the maquette, beams protrude from the wall in anticipation.

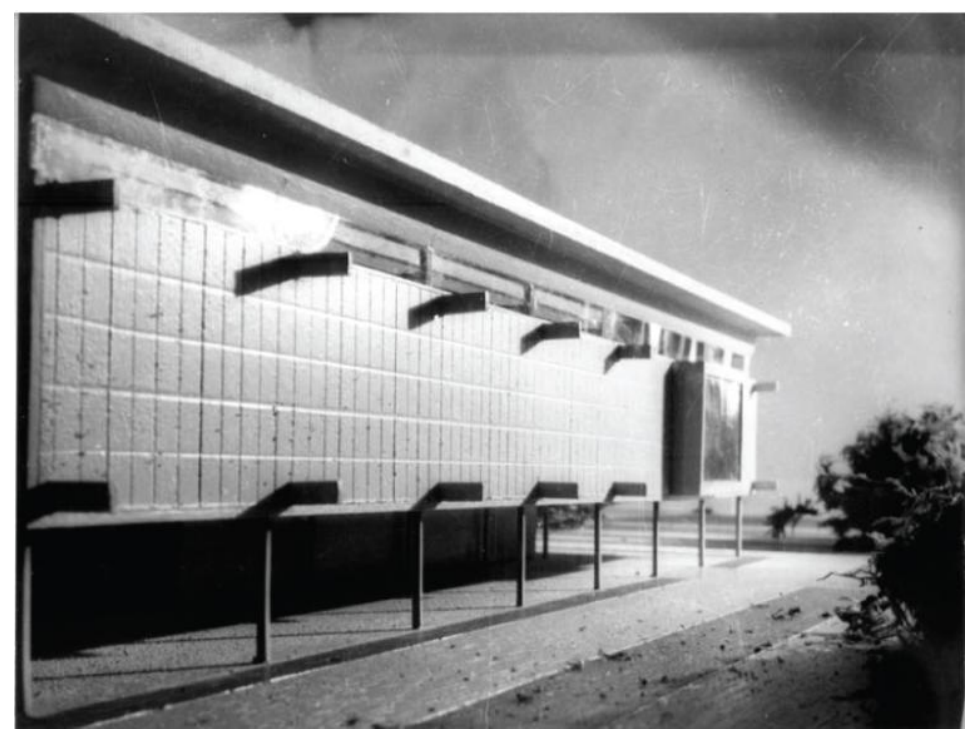

7. Musée à croissance illimitée, maquette. (C) FLC/ADAGP

The outer layer is only a temporary facade that will eventually become interior partitions. The spiraling future pattern of growth is marked on the ground around the box and the model shows the box covering 1,000 square meters and expanded to 3,000 square meters. Therefore, the museum is an ever-expanding interior without a definitive exterior. Beatriz Colomina has described the endless museum as "a machine for swallowing the outside. "19 The wall is more than a skin or surface for projected meanings or expressions, but a wholly active organ, an entity that carries with it the vitality of the entire project.

With regard to the power of the wall, Le Corbusier has said - A wall is beautiful, not only because of its plastic form, but because of the impressions it may evoke. It speaks of comfort, speaks of refinement; it speaks of power and of brutality; it is forbidding or it is hospitable; - it is mysterious. A wall calls forth emotions. ${ }^{20}$

And here, we can refer to the famous anecdote of the "poem of walls" which Le Corbusier created for his client in La Maison Roche. ${ }^{21}$ Raoul La Roche felt that the architectural expression of Le Corbusier's walls

\footnotetext{
${ }^{18}$ Le Corbusier et Pierre Jeanneret, "Pour la création a Paris d'un musée des artistes vivants," Cahiers d'art, année 6, no.1 (1931): 7.

${ }^{19}$ Beatriz Colomina, "The Endless Museum: Le Corbusier and Mies van der Rohe," Log no. 15 (Winter 2009): 57.

${ }^{20}$ Le Corbusier quoted in A. Vidler, The Architectural Uncanny: Essays in the Modern Unhomely. (Cambridge, MA: MIT Press, 1992): 90.

21 "Remember the origin of my undertaking 'La Roche, when one owns as superb a collection of art as yours, one must build a house which is worthy of it.' And my answer: 'Very well, Jeanneret, build me that house.' But, what has happened? The house once finished was so beautiful that when I saw it, I cried out to myself: 'It's almost a crime to put paintings in it.' I put them in anyway. Could I have done anything but? Do I not have certain obligations to my painters, of whom you are one, by the way? I ordered a 'framework for my collection'. You made me a 'poem of walls'. Which of the two of us has been the
} 
overwhelmed the artistic expression of his collection. Perhaps, as one of Le Corbusier's seminal villa projects of the 1920s, this marks a critical point in his investigation of the surface of the wall. As discussed in the first section, I argue that the museum projects of the 1930s takes on an expanded perspective, and formal approach. Le Corbusier insists, here, on a subversion of face, although in the realized projects, there are nuances which respond to the specificities of the project sites.

In Tokyo, katsura-hama, green and grey pebbles, are embedded into the concrete of the National Museum of Western Art's exterior walls, and himeko-matsu pine wood grain of the formwork is imprinted on its round columns. In Ahmedabad and Chandigarh, local Indian bricks are vibrant red. However, these details serve more of a functional purpose than one of aesthetics. The window-less wall provides insulation. The prominent concrete guttering above the pilotis is intended to accommodate a particular kind of climbing plant which will shade the wall from the sun's heat. Mud-brick and stone are used in a rough manner as part of Indian vernacular. C'est le tabernacle de l'art moderne, mais il est pauvre comme une crêche. The museum is a temple of modern art, but it is poor like a manger. Beyond style or symbolism, without ostentation or signification, Le Corbusier's faceless museum was an anti-monument which Anthony Vidler describes as a method of criticality. "In these respects, then, the notion of an escape from or effacement of monumentality would seem to turn back on itself, implying the immediate absorption of the most "critical" vocabulary of references and the monumentalization of any institutional form, however veiled its "soul." The very eradication of the face that veils representation becomes symbolic in its own right, monumentalizing, despite itself, the most difficult contradictions in the debate over monumentality." 22 The neutrality of the Musée is taken as a method of resistance, which opens up the potential for signification, a degree zero of architectural expression.

\section{Place-less}

Le musée s'élève dans quelque banlieue ou grande banlieue de Paris. Il s'élève au milieu d'un champ de pommes de terre ou de betteraves. Si le site est magnifique, tant mieux. S'il est laid et attristé de pignons de lotissements ou de cheminées d'usines, ça ne fait rien. ${ }^{23}$

Although Le Corbusier's comment about the irrelevance of the beauty of the site was flippant, the mention of beets and potatoes relates to agriculture and cultivation, alluding to ideas of earth and the museum as a sacred space of cultural formation - grounds for the cultivation of the human spirit. The juxtaposition of an agricultural field with an industrial landscape, vastly different scenes, adds emphasis to his point that the Museum of Unlimited Growth can exist within any and all contexts.

Whereas the relationship between landscape, site, and building was significant for the domestic projects of Le Corbusier - the ribbon window establishing a connection between inside and outside through the wall - the museum was instead an introverted space, a continuous wall constantly unfolding and folding back onto itself. Pilotis would elevate the building, but unlike the way they were employed in his other projects, here they did not

most to blame?" Roche quoted in Stanislaus von Moos, Le Corbusier: Elements of a Synthesis (Cambridge: MIT Press, 1979): 266.

${ }^{22}$ Vidler, The Architectural Uncanny, 95.

${ }^{23}$ The museum rises in some suburb of Paris, set in the middle of a field of potatoes or beetroot. If the site is magnificent, so much the better. If it is ugly and saddened by sprocket-wheel developments or factory chimneys, it doesn't matter. 
serve to create circulation and public space on the ground level. Le Corbusier notes that this space below the galleries can serve as storage for the art, so the elevation of the building off the ground does have some functional reasoning. However, it is important to distinguish that in the case of the museum projects, the pilotis serve more of a symbolic purpose. By lifting the building from the earth, Le Corbusier removes the institution from its historical and cultural context. Place-less, the Museum of Unlimited Growth is unbound to nation or state, being of no-where and every-where.

Without delving too deeply into the political climate of Paris in 1931, (as scholarship on Le Corbusier's political values remains controversial and a divisive issue) it is worth acknowledging the relationship between museums and nationhood throughout history in brief, as it pertains to the discussion of architecture and place-making.

When early art collections from royal collections were made public to the general populace, they were still presented within princely palaces. The Louvre opened to the public in 1789 but the presence of the monarch, the body of the king, was very much part of the aura of the physical space of the gallery rooms. After the Napoleonic period, as nation states sought to reclaim and reassert their identity, the notion of site and place was of utmost importance, as an extension of power and authority. Architecture had the unique agency, apart from other major arts, to signify place. In a post-revolutionary context, colonial territories once emancipated would seek to cultivate their own sense of cultural legitimacy through the establishment of museums. Although the content within early American art museums would still be Euro-centric, architecture of the neo-classical order would serve to represent a young nation's cultural refinement. Through the collection and organization of objects, the exclusion of some, the appropriation of others, the space of the museum would establish a semblance of a collective history. Museums have therefore been critical in the projection of ideas of place, of borders, of territories.

The museum as a site has always confronted the problem of decontextualization, the removal of an art object from the artist's studio or a cultural artifact from its place of origin. Furthermore, the efficacy of cultural preservation through museums is arguable. However, the Sanskar Kendra Museum, Museum Director would defend his institution. "The modern museum that Le Corbusier created would bring about the active participation of people, instead of encouraging mere irresponsible contemplation of rare luxury objects torn from their contexts." ${ }^{24}$ His disciple Balkrishna V. Doshi would insist that, "Even as it addresses the Indian context, the city nevertheless remains international in carácter and gives us Le Corbusier's sense of the future not [a present] Indian life.",25

The National Museum of Western Art in Tokyo is a complex scenario, in which issues of repatriation are involved. It was agreed upon that Le Corbusier would design the museum in order for the French government to return the Japanese collector's holdings after the Second World War. Despite the socio-political implications of these commissions, the architecture stands alone with its concepts of order-less-ness and face-less-ness contributing to a quality of unspecific, place-less-ness.

\footnotetext{
24 "Le Corbusier: Sanskar Kendra Museum, Ahmedabad, India 1957." A \& U: Architecture \& Urbanism no. 5 (May 2001): 45.

${ }^{25}$ Jon T. Lang, A Concise History of Modern Architecture in India (New Delhi: Permanent Black, 2002): 65.
} 
Beyond these three realized projects, Le Corbusier imagined Museums of Unlimited Growth for nations across the world - from France to Japan, Switzerland to Africa, Germany to India. The idea for a Museum of Unlimited Growth was refined over many iterations. First, in 1931 was the proposal for the Cahiers d'art, sans lieu; then a Centre d'esthétique contemporaine located in Paris, France in 1937; later an exploration for Philippeville, Africa in 1939; a decade after the three realized commissions, he would envision a Centre d'art international in Erlenbach, Germany located at the crossing of axes of Stockholm-Rome and Paris-Vienna-Belgrade-Bucarest in 1962; and a sketch for a Musée du Xxe siècle to be located in Nanterre, France would be his last drawing dated 29 June 1965. Perhaps he was envisioning a global network all along.

Transcultural and transnational, the original proposal and subsequent versions of the spiral museum captured the spirit of modernity. In a comparison of Mies van der Rohe and Le Corbusier's world views, Beatriz Colomina anecdotally points to how the former would rather travel by ocean liner or train, while the latter loved to fly. As it relates to the siting of their work, Mies's buildings, like the architect, can be seen as obstinate and steadfast; while Le Corbusier, in his mobility and hunger for travel, is expressive of a desire for his work to have equal reach, an architecture that can be nomadic and universal.

The idea for a World Museum actually preceded that of the Museum of Unlimited Growth. The Mundaneum was to be a global archive, a Roneo File Cabinet for the world and all of its knowledge. "Our desire is that in one place on the globe the total image and significance of the world should be visible and understood." 26 The Mundaneum from 1929 by Paul Otlet and Henri La Fontaine was the first instance of an attempt to spatialize a globally networked world, an attempt at internationalism. The Mundaneum was not just a project for a real building, but also an architectural metaphor of knowledge organization and dissemination on a global level, a building and a network ${ }^{27}$ - both a material and a virtual construction.

In The Delirious Museum, Storrie argues that in some ways, the theft of the Mona Lisa in 1911 from the Louvre marked the beginning of art's "ambivalent relationship" ${ }^{28}$ with the museum. At that moment, the illusion of the authority of architecture and the authority of the museum was broken. Le Corbusier's design for the Musée and his explorations into traveling exhibition displays challenged the notion of artistic experience's relationship to place. As he describes - a Modular PREPARATION OF A TRAVELLING EXHIBITION (under the auspices of six major American museums). ${ }^{29}$ By the use of the Modulor the panels for the pictures were able to accommodate every imaginable shape and size. They were afterwards demounted and re-erected abroad. The permanent shelter offered by "project B" allowed sister-organizations abroad to come and exhibit in Paris. This type of metal parasol or umbrella could be adopted in Milan, London, Berlin, etc. So with Paris as a centre the circuit which would be set up would stimulate an intensification of the researches into the relationship of the Major Arts and architecture.

His architectural projects can be interpreted as a formal representation of his way of seeing and being in the world. The Athens Conference (1931) on restoration of historic buildings was organised by the International

\footnotetext{
${ }^{26}$ W. Boyd Rayward, "Visions of Xanadu: Paul Otlet (1868-1944) and Hypertext," Jasis 45 (1994): 235.

${ }^{27}$ Charles van den Heuvel, "Architectures of Global Knowledge: the Mundaneum and the World Wide Web," Volume no. 15 (2008): 49.

${ }^{28}$ Calum Storrie, The Delirious Museum: A Journey from the Louvre to Las Vegas (London: I.B. Tauris, 2006): 12.

${ }^{29}$ Le Corbusier, Modular I (Paris, 1948): 154.
} 
Museums Office, and the Athens Charter ${ }^{30}$ was drafted by Le Corbusier at the fourth Assembly of the International congresses on Modern Architecture (1933). Published in 1941, this reflected a growing consciousness among specialists all over the world, and introduced for the first time in history the concept of international heritage. As a project developed under these influences, the Museum of Unlimited Growth is an attempt at an autonomous architecture, beyond style or traditions. By subverting the notion of site, Le Corbusier achieved an architecture with authority over politics, undoing any obligation to cultural burdens. Place-less - the Museum of Unlimited Growth turns the visitor's attention and consciousness instead towards an inner, metaphysical space for the synthesis of knowledge and the arts.

\section{End-less}

Le musée est extensible à volonté: son plan est celui d'une spirale; véritable forme de croissance harmonieuse et régulière. ${ }^{31}$

Hannes Meyer famously said, "All things in the world are a product of the formula: Function times economy." Le Corbusier echoes this maxim, noting that successful architecture must be "inspired by the law of Economy and governed by mathematical calculation." 32 He understood very well the role of economic factors and issues of utility. To this end, he applies a modular, flexible wall system. Poteaux standard, cloisons-membranes fixes ou amovibles, plafonds standard. Économie maximum. He also acknowledges in the proposal that expansion would happen through private donorship. In the Museum of Unlimited Growth, a donor would attach his name not only to a work of art, but also to the very wall which would support the painting. That Le Corbusier would mention museum operations to this level of detail reveals that he was not naïve to the fact that architects' intellectual and artistic visions are influenced by matters of funding.

\footnotetext{
${ }^{30}$ Athens Charter for the Restoration of Historic Monuments Preservation, accessed through International Council on Monuments and Sites www.icomos.org.

${ }^{31}$ The museum is extendable at will: a plan which is that of a spiral; true form of harmonious and steady growth.

${ }^{32}$ Le Corbusier, Vers une architecture, 11.
} 


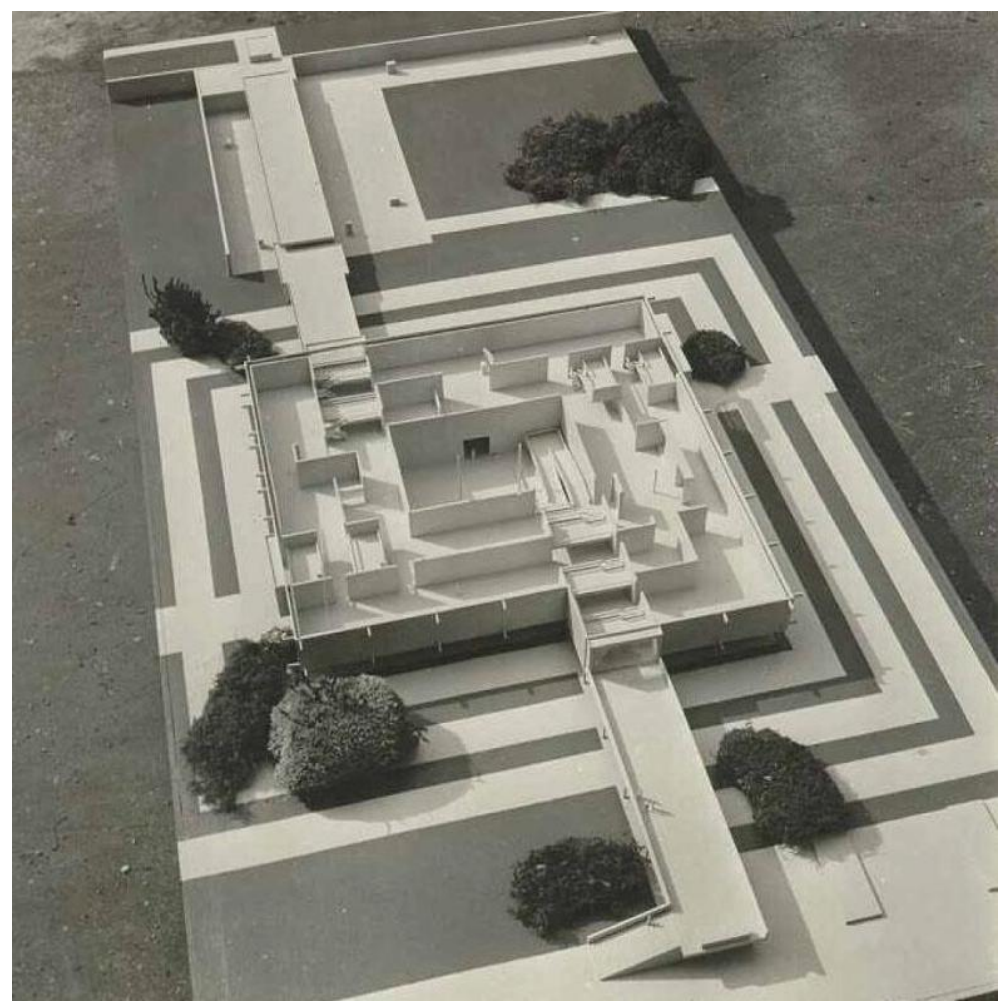

8. Musée à croissance illimitée, maquette. (C) FLC/ADAGP

Along with the bold scheme of unlimited growth, Le Corbusier's architecture trumps ideas of style or utility. The spiral is an end-less figure that allows for end-less representation and interpretation of culture. Le Corbusier argued that architecture - not fashion or technology - through concepts of order and harmony, becomes poetry that can be eternal: I have allowed a spiral staircase (very modern, and also timeless), spiral ramps (the same vertical circulation as the Tsentrosoiuz in Moscowvary modern and also very old!); I have allowed the museum of human creation to follow a spiral, not to be "the last word in fashion," but to assure, through this unique means, the absolute continuity of events in history. I cannot see any other way of doing it. ${ }^{33}$

Le Corbusier imagined that a modern museum, a true museum, would include the present day, the every day, the quotidian. In the Library of Babel (1941) Jorge Luis Borges imagined the universe as an infinite collection of books, a labyrinthian storehouse of knowledge. Gustave Flaubert's satire Bouvard et Pécuchet (1881) is a story about the pursuit, the impossibility and futility of attempting to build encyclopedic knowledge. Both stories attempt to illustrate theories of epistemology, about the complexities of collection and heterogenity. Nonetheless, Le Corbusier presented a provocation. "Let us imagine a true museum, one that contained everything, one that could present a complete picture after the passage of time, after the destruction by time (and how well it knows how to destroy! So well, so completely, that almost nothing remains except objects of great show, of great vanity, of great fancy). ",34

Le Corbusier understood that there was a "cap" and realistically, the museum would not grow "infinitely." It is unclear how he envisioned the collection would develop after the museum reached its maximum dimension of

\footnotetext{
33 "In Defense of Architecture," republished in Oppositions Reader: Selected Essays 1973-1984 (New York: Princeton Architectural Press, 1998): 608.

${ }^{34}$ Le Corbusier, L'art décorative d'aujourd'hui (Paris: G. Crès et Cie, 1924): 16.
} 
nine thousand meters square. But it holds then, that beyond the ideas of physical growth is an idea of conceptual growth and that the projective and expansive form goes beyond built space to metaphysical space. The paradox of an endless museum allows one to contemplate the past while recognizing one's position in history, all the while conscious of the future to come.

\section{Conclusion (Time-less)}

The museum as a typology was a topic of patient research, contemplated over the course of Le Corbusier's entire career. His museums in India and Tokyo are versions of an impossible ideal, but through the analysis of the original proposal and subsequent iterations, we see the careful consideration of a means to synthesize art and architecture. Perhaps the concepts which have structured my argument can also be taken as the very qualities for which modernism is criticized: the order-less museum can be interpreted as determinist and monolithic; the faceless building has no poetry or soul; place-less, the project is anonymous, insensitive in fact; and end-less, the architecture becomes relentless and oppressive. However, one can argue that these aspects of the museum of unlimited growth allows it to literally project from its physical footprint and figuratively extend beyond its own moment in history. In its radical form, the spiral figure enframes an understanding of time - by resisting the forces of time.

It is a daunting task to engage with the many facets of Le Corbusier's body of work. From analyses of his villas as machines for living, to discussions of his urban projects to the study of the poetics of Ronchamp's primitive sculptural forms - scholarship on Le Corbusier's œuvre has largely overshadowed and overlooked the spiral museum projects. Yet, in the minimal spiral plan museum one can trace the development of a distinct position regarding the relationship of space and time. In his brief 1931 letter to Zervos, he laid the seeds for an obscure, yet meaningful project, one concerned pure potentiality and the limits of architecture.

\section{Source of Images}

(C) FLC/ADAGP Fondation Le Corbusier/Société des Auteurs dans les Arts Graphiques et Plastique.

\section{Bibliography}

Brooks, H. Allen, eds. Le Corbusier. New York, NY: Princeton University Press 1987.

Colomina, Beatriz. "The Endless Museum: Le Corbusier and Mies van der Rohe." Log no. 15 (Winter 2009): 5568 .

Crimp, Douglas. On the Museum's Ruins. Cambridge, MA: MIT Press, 1993.

Foster, H. The Art-Architecture Complex. London: Verso, 2011.

Hays, K. Michael. Oppositions Reader: Selected Readings from a Journal for Ideas and Criticism in Architecture, 1973-1984. New York, NY: Princeton Architectural Press, 1998.

Heuvel, Charles van den. "Architectures of Global Knowledge: the Mundaneum and the World Wide Web." Volume no. 15 (2008): 48-53.

Kokuritsu Seiyō Bijutsukan. Thirty Years of the National Museum of Western Art Tokyo: 1959-1989. Tokyo: 国立西洋美術館，1989.

Lang, Jon T. A Concise History of Modern Architecture in India. New Delhi: Permanent Black, 2002.

"Le Corbusier: Sanskar Kendra Museum, Ahmedabad, India 1957." A \& U: Architecture \& Urbanism no. 5 
(May 2001): 42-49.

Le Corbusier et Pierre Jeanneret. "Pour la création a Paris d'un musée des artistes vivants." Cahiers d'art, année 6, no.1 (1931): 5-9.

Le Corbusier.

Vers une architecture. Paris: G. Crès et Cie, 1924.

L'art décorative d'aujourd'hui. Paris: G. Crès et Cie, 1924.

Le Modulor. Paris, 1948.

Le Modulor II. Paris, 1950.

L'atelier de la recherche patiente.Translated by James Palmes. New York: Praeger, 1960. 1930-71

Euvre Complètes, 1910-65, pubished in 8 volumes, edited by Willy Boesiger. Zurich, Girsberger,

The Le Corbusier Archive, in 32 volumes, edited by Allen H. Brooks. New York, NY:

Garland Architectural Archives, 1982-84.

Moos, Stanislaus von. Le Corbusier: Elements of a Synthesis. Translated by Beatrice Mock, Joseph Stein, and Maureen Oberil. Cambridge: MIT Press, 1979.

Rayward, W. Boyd, "Visions of Xanadu: Paul Otlet (1868-1944) and Hypertext." Jasis 45 (1994): 235-50.

Samuel, Flora. Le Corbusier and the Architectural Promenade. Basel: Birkhäuser, 2010.

Searing, Helen. New American Art Museums. New York, NY: Whitney Museum of American Art, 1982.

Serenyi, Peter. “Timeless but of Its Time: Le Corbusier's Architecture in India.” Perspecta vol. 20 (1983): 91 118.

Storrie, Calum. The Delirious Museum: A Journey from the Louvre to Las Vegas. London: I.B. Tauris, 2006.

Vidler, Anthony. Architecture between Spectacle and Use. Williamstown, MA: Sterling and Francine Clark Art Institute, 2008.

Vidler, A. "Losing Face: Notes on the Modern Museum." Assemblage no. 9 (June 1989): 40-57.

Vidler, A. Warped Space: Art, Architecture, and Anxiety in Modern Culture. Cambridge, MA: MIT Press, 2000.

Vidler, A. The Architectural Uncanny: Essays in the Modern Unhomely. Cambridge, MA: MIT Press, 1992. 